ljtihad, Jurnal Wacana Hukum Islam dan Kemanusiaan

Vol. 16, No. 1 (2016), pp. 43-66, doi : 10.18326/ijtihad.v16i1.43-66

\title{
Penyelesaian sengketa letter of credit ekspor-impor syariah pascaputusan Mahkamah Konstitusi Nomor 93/PUU-X/2012
}

\author{
Titik Triwulan Tutik \\ Fakultas Syariah dan Hukum Universitas Islam Negeri Sunan Ampel Surabaya \\ E-mail:tt_titik@yahoo.com \\ DOI:10.18326/ijtihad.v16i1.43-66
}

This research is aimed to examine on the dispute settlement Letter of Credit (L/C) Import-Export in sharia banking. This dogmatic study was supported by the statute and conceptual approach. The steps of research were conducted by collecting the primary and secondary data. All of the data were noted using card system based on the subjects of the research problem and writing system. The results of the research show that: First, the position of the Letter of Credit as cross-border transactions in the Sharia banking, not only just set in national contract law, but also stipulated in the International treaty provisions do not contrast with the principles of Sharia. Secondly, in the event of dispute resolution issues of Islamic banks, according to Constitutional Court Decision No. 93/PUU-X/2012 can use two (2) that litigation and non-litigation. A litigation path into the absolute authority of religious courts, while the path of non-litigation the parties can make a choice no explanation as specified in Article 55 paragraph (2) of Law Number 21 Year 2008 concerning Sharia Banking but can also take other alternatives in accordance with a contract that banks have agreed.

Penelitian ini mengkaji tentang bagaimana penyelesaian sengketa Letter of Credit (L/C) Ekspor-Impor dalam perbankan syariah. Penelitian ini merupakan penelitian dogmatik dengan pendekatan perundangundangan (statute approach); dan pendekatan konsep (conceptual approach). Langkah penelitian dilakukan menghimpun bahan-bahan primer dan sekunder semuanya dicatat dengan menggunakan sistem kartu (card system) yang disusun berdasarkan pokok permasalahan penelitian dan sistematika penulisan. Hasil menunjukkan, bahwa: Pertama, kedudukan Letter of Credit sebagai transaksi antar negara dalam perbankan syariah, tidak hanya hanya diatur dalam hukum perjanjian nasional tetapi juga diatur dalam perjanjian Internasional dengan ketentuan tidak betentangan dengan prinsip syariah. Kedua, dalam hal terjadi permasalahan penyelesaian sengketa bank syariah menurut Putusan Mahkamah Konstitusi Nomor 93/ PUU-X/2012 dapat menggunakan 2 (dua) yaitu litigasi dan non litigasi. Jalur litigasi menjadi kewenangan absolut peradilan agama, sedangkan jalur non-litigasi para pihak dapat melakukan pilihan tidak sekedar 
ljtihad, Jurnal Wacana Hukum Islam dan Kemanusiaan, Volume 16, No.1, Juni 2016: 43-66

sebagaimana ditentukan dalam Penjelasan Pasal 55 ayat (2) Undang-Undang Nomor 21 Tahun 2008 tentang Perbankan Syariah tetapi dapat juga menempuh alternatif lain sesuai dengan akad yang tekah disepakati.

Keywords: Letter of credit (L/C); The transaction sharia; Sharia banking dispute; Islamic finance

\section{Pendahuluan}

Sistem keuangan Islam dalam perkembangannya tidak hanya diminati di negara-negara yang penduduknya mayoritas beragama Islam, tetapi juga telah menarik perhatian para bankir Barat terutama Eropa. Metode pembiayaan Islam telah dipandang sebagai suatu tantangan sekaligus peluang bagi mereka yang berkecimpung dalam bisnis keuangan modern di Barat. Hal ini dimungkinkan terutama adanya fenomena masyarakat industri yang didorong oleh tuntutan klien dalam nuansa bisnis modern. Pada masyarakat demikian, selalu timbul kesediaan dari pihak pengelola lembaga keuangan untuk senantiasa mendengarkan dan mempelajari perkembangan dan pengalaman bank-bank Islam yang diperkirakan akan menjadi sebuah trend baru dalam sistem keuangan dunia (Basri, 2002). Prospek perdagangan internasional yang terus mengalami perkembangan dewasa ini, antara lain melalui kegiatan ekspor impor, merupakan salah satu peluang yang besar bagi perbankan syariah untuk ikut menggembangkan bisnisnya dalam tingkat internasional.

Ada banyak hal yang dapat dikembangkan oleh perbankan syariah melalui kegiatan eksporimpor ini, di antaranya ikut ambil bagian dalam pembiayaan berdasarkan prinsip syariah, maupun sebagai sarana pembayaran. Hinkelman (2002), mengklasifikasi 4 (empat) metode pembayaran dalam perdagangan internasional, yaitu: Pertama, Cash in Advance; di mana importir membayar sebelum barang yang dipesannya dikirim. Persyaratan ini menuntut agar pembeli memiliki tingkat kepercayaan yang tinggi terhadap kemampuan dan kemauan penjual untuk menyerahkan barang yang dipesannya. Kedua, Open Account, di mana Eksportir sepakat untuk membayar dalam waktu yang telah ditetapkan, biasanya dalam waktu 30, 60, atau 90 hari. Dengan demikian eksportir mengandalkan kemampuan dan kemauan importir untuk membayar barang yang telah dikirimkannya. Pada sistem pembayaran ini, memberi risiko yang kecil bagi importir, tetapi eksportir menanggung risiko yang besar. Ketiga, Docu- 
mentary Collection; adalah cara pembayaran yang sama dengan metode cash on delivery (COD/ tunai begitu barang diserahkan). Ekspotir menyerahkan barang kepada importir tetapi juga menyerahkan dokumen, termasuk bill of lading (dokumen kepemilikan barang) melalui bank dengan instruksi untuk menyerahkan dokumen tersebut setelah importir membayar melalui bank tersebut. Setelah importir memperoleh dokumen kepemilikan (bill of lading), dia memiliki hak untuk mendapatkan barang yang dikirimkan tersebut. Keempat, Letter of Credit (L/C); adalah janji bank untuk membayar eksportir atas nama importir sepanjang eksportir eksportir memenuhi persyaratan dan kondisi yang ditetapkan dalam letter of credit. Letter of credit memberi kedudukan keamanan dan risiko sama baik kepada eksportir maupun importir .

Dewan Syariah Nasional Majelis Ulama Indonesia (DSN MUI) Nomor 34/DSN-MUI/ IX/2002 tentang L/C Impor Syariah mendefinisikan L/C adalah surat pernyataan akan membayar kepada importir yang akan diterbitkan bank untuk kepentingan importirir dengan pemenuhan persyaratan tertentu sesuai dengan prisip Syariah. Kasmir (2002: 152) mendefinisikan L/C adalah suatu pernyataan dari bank atas permintaan nasabah (importir) untuk menyediakan sejumlah uang tertentu untuk kepentingan pihak ketiga (penerima L/C atau eksportir). L/C syariah sebagai primadona dalam pembayaran pada transaksi perdagangan internasional sebagai kegiatan ekspor impor dinilai memberikan kepastian dan keamanan. Namun demikian, keberadaan L/C Syariah tersebut belum banyak dikenal dan dipergunakan oleh para pebisnis Indonesia.

Permasalahannya adalah bagaimanakah jalur penyelesaian jika terjadi sengketa pada sistem transaksi dalam perbankan syariah dengan menggunakan L/C sebagai alat pembayaran, khususnya mengenai aturan hukum mana yang berlaku dan lembaga mana yang memiliki kewenangan dalam menyelesaikan sengketa tersebut? Hal ini cukup dipahami, mengingat L/C pada dasarnya merupakan alat bayar untuk sesuatu transaksi ekspor-impor. Sebagai transaksi antar negara, maka pengaturan hukum atas Letter of Credit tersebut diatur dalam perjanjian Internasional (bukan perjanjian Nasional/Indonesia) yang dikuti oleh semua Negara-negara di dunia, yaitu menggunakan UCP.500 (United Custom Practice 500).

Penyelesaian sengketa bank syariah menurut Penjelasan Pasal 55 ayat (2) Undang-Undang Nomor 21 Tahun 2008 tentang Perbankan Syariah pada umumnya dapat menggunakan jalur peradilan umum, selain jalur peradilan agama dan arbitrase. Pemilihan forum (choice of 
ljtihad, Jurnal Wacana Hukum Islam dan Kemanusiaan, Volume 16, No.1, Juni 2016: 43-66

forum) ini pada realitanya menurut Muhammad Syafi'i Antonio (2012) menimbulkan pertentangan berbagai lembaga penyelesaian sengketa (conflict od dispute settlement), yang pada akhirnya menimbulkan ketidakpastian hukum. Atas dasar hal tersebut Putusan Mahkamah Konstitusi Nomor 93/PUU-X/2012, Mahkamah Konstitusi menyatakan bahwa adanya pilihan tempat penyelesaian sengketa (choice offorum) untuk menyelesaikan sengketa perbankan syariah sebagaimana tersebut dalam Penjelasan Pasal 55 ayat (2) Undang-Undang Nomor 21 Tahun 2008 pada akhirnya akan menyebabkan adanya tumpang tindih kewenangan untuk mengadili, karena ada dua peradilan yang diberikan kewenangan untuk menyelesaikan sengketa perbankan syariah, padahal dalam Undang-Undang Nomor 3 Tahun 2006 tentang Peradilan Agama secara tegas dinyatakan bahwa peradilan agama yang berwenang menyelesaikan tersebut.

Dengan adanya putusan Mahkamah Kontitusi tersebut, maka tidak ada lagi dualisme dalam penyelesaian sengketa Perbankan Syariah. Pengadilan Agama menjadi satu-satunya pengadilan yang berwenang dalam menyelesaikan sengketa Perbankan syariah. Namun demikian ada permasalahan hukum lain yang dapat muncul dalam ketentuan hukum positif yang dipakai oleh hakim dalam mengadili sengketa L/C tersebut. Pertama, dalam penyelesaian sengketa perdata melalui badan peradilan Indonesia pada umumnya menggunakan ketentuan berdasarkan KUH Perdata. Sementara itu ketentuan L/C ekspor-impor syariah merupakan transaksi antar negara sehingga tidak semata tunduk pada ketentuan hukum nasional, tetapi juga diatur dalam perjanjian Internasional dan dan dalam transaksinya tidak boleh bertentangan dengan ketentuan Syariah Islam. Kedua, di pihak lain apakah dalam penyelesaian sengketa melalui jalur non-litigasi masih tetap menggunakan sebagaimana dimaksud dalam Penjelasan Pasal 55 ayat (2) Undang-Undang Nomor 21 Tahun 2008, ataukah ada jalur non-litigasi lainnya?

Berdasarkan latarbelakang masalah tersebut, yang menjadi sasaran kajian dan sekaligus pertanyaan (isu) penelitian yang memerlukan jawaban adalah: Bagaimanakah keberadaan dari undang-undang yang mengatur tentang Letter of Credit dalam transaksi perbankan syariah? Selanjutnya, bagaimanakah perjanjian antara nasabah dengan bank dalam menentukan pihak yang berwenang menyelesaikan sengketa Letter of Credit dalam sistem transaksi perbankan? 


\section{Teori dan penelitian sebelumnya}

Penelitian ini dilakukan dengan menggunakan teori maslahah dan sistem hukum (legal system) yang terangkai dengan teori penyelesaian sengketa. Teori-teori di maksud dijadikan pisau analisis sekaligus wacana dalam menganalisis dan menjelaskan masalah yang akan diteliti. Selain itu, kajian didukung teori Economic Analysis of Law yang berkaitan dengan konsep efisiensi penyelesaian sengketa perbankan syariah.

Al-Juwayni berpandangan bahwa maslabah merupakan indikator dalam penentuan keberadaan hukum. Maslahah pada hakikatnya tidak lain adalah maqāsid atau tujuan dari syariat dalam menetapkan hukum (Yuslem, 2007: 5). Pemikirannya tentang maslaḥah ini kemudian diadopsi dan dikembangkan oleh muridnya Ghazali (Yuslem, 2007: 10).

Kemaslahatan senantiasa bersandar pada syariah, dan hanya dapat diaplikasikan dalam bidang muamalah yang berkaitan dengan hubungan sesama manusia yang lebih menerima rasionalitas dibandingkan dengan bidang ibadah yang bersifat transedental (Mahmassani, 1981: 137). Prinsip dalam bagian ibadah adalah ta'abbudi dan hukum ibadah itu diketahui dengan dalil-dalil syariah. Bagian muamalah mempunyai makna yang bisa diterima oleh akal dan didasarkan atas kemaslahatan manusia. Maslahat yang menjadi dasar mengantisipasi setiap perubahan dalam kehidupan masyarakat yang dapat memengaruhi keberadaan hukum senantiasa harus serasi dengan tujuan hukum Islam.

Penulis telah melakukan penelusuran terhadap berbagai referensi baik yang melalui media cetak maupun media elektronik. Tulisan dengan Judul "Aspek Hukum Penyelesaian sengketa Perbankan Syariah Menurut Undang-Undang Nomor 3 Tahun 2006 Tentang Peradilan Agama" telah ditulis oleh Herlangga (2011), yang fokus penelitiannya membahas tentang aspek hukum penyelesaian sengketa perbankan syariah melalui jalur litigasi dan non litigasi menurut Undang-Undang Nomor 3 Tahun 2006 tentang Peradilan Agama dan Undang-Undang Nomor 21 Tahun 2008 tentang Perbankan Syariah. Kemudian terdapat karya dengan judul "Analisis Hukum Terhadap Dualisme Penyelesaian Sengketa Ekonomi Syariah Pasca Perlakunya Undang-Undang Nomor 48 Tahun 2009 Tentang Kekuasaan Kehakiman" oleh Rahim (2011) yang fokus penelitiannya membahas tentang ranah politik hukum Indonesia serta dampaknya terhadap kewenangan absolut Peradilan Agama. Selain itu, studi dengan judul "Kewenangan Pengadilan Agama dalam Penyelesaikan Sengketa 
ljtihad, Jurnal Wacana Hukum Islam dan Kemanusiaan, Volume 16, No.1, Juni 2016: 43-66

Ekonomi Syariah Ditinjau dari Segi Hukum Perjanjian” oleh Tarigan (2011), yang fokus penelitiannya membahas tentang kewenangan Peradilan agama dalam memutus sengketa ekonomi syariah apabila salah satu pihak merupakan non muslim dan eksistensi putusan perkara syariah apabila akad mengatur untuk penyelesaian sengketa diajukan pada Pengadilan Negeri.

Judul "Analisis Hukum Terhadap Kewenangan Peradilan Umum dalam Penyelesaian Sengketa Perbankan Syariah Pasca Putusan Mahkamah Konstitusi Nomor 93/PUU-X/ 2012" oleh Dewi membahas tentang alasan lahirnya kewenangan Pengadilan Negeri dalam penyelesaian sengketa perbankan syariah dan dampaknya pasca putusan Mahkamah Konstitusi Nomor 93/PUU-X/2012 serta akibat hukum yang ditimbulkan terhadap akad yang memuat klausula penyelesaian sengketa melalui Pengadilan Negeri. Judul penelitian setema selanjutnya adalah "Prinsip Arbitrase Berbasis Syariah dalam Penyelesaian Sengketa Perbankan Syariah" karya Arifin (2014). Fokus penelitian ini membahas tentang alasan lahirnya kewenangan Arbitrase dalam penyelesaian sengketa perbankan syariah pasca putusan Mahkamah Konstitusi Nomor 93/PUU-X/2012 serta akibat hukum yang ditimbulkan.

Penulisan yang diangkat oleh penulis berbeda dengan penulisan penelitian tersebut, perbedaannya terletak pada pokok kajian. Penelitian penulis memfokuskan diri pada penyelesaian sengketa letter of Credit (L/C) ekspor-impor syariah, baik secara litigasi maupun non litigasi. Dengan demikian dapat penulis simpulkan bahwa belum ada penelitian yang identik dengan penelitian yang penulis angkat dengan Dengan demikian penelitian ini dapat dikatakan memenuhi kaidah keaslian penelitian.

\section{Metode penelitian}

Jenis penelitian ini adalah penelitian hukum normatif (dogmatic) yang ditujukan untuk menemukan dan merumuskan argumentasi hukum, melalui analisis terhadap pokok permasalahan (Hadjon, 1994: 2). Pendekatan yang digunakan dalam penelitian ini ada dua jenis yaitu: statute approach dan conceptual approach. Langkah-langkah penelitian yang dilakukan adalah menghimpun bahan-bahan hukum baik bahan hukum primer maupun bahan hukum sekunder yang berkaitan dengan topik penelitian. Terhadap bahan hukum sekunder semuanya dicatat dengan menggunakan sistem kartu (card system). Kartu-kartu disusun berdasarkan 
pokok permasalahan penelitian dan sistematika penulisan yang telah dirumuskan.

Semua hasil penelitian yang diperoleh dari bahan-bahan hukum tersebut di atas dicari hubungannya antar satu dengan lainnya dengan menggunakan penalaran deduktif dan induktif untuk menghasilkan proposisi dan konsep baik berupa definisi, deskripsi maupun klasifikasi sebagai hasil penelitian.

\section{Pengaturan letter of credit dalam perbankan syariah}

L/C dalam bahasa Indonesia disebut sebagai Surat Kredit Berdokumen merupakan jasa bank yang diberikan kepada masyarakat untuk memperlancar arus barang selain dalam negeri (antar pulau) juga antar negara (ekspor-impor). L/C secara sederhana merupakan pengambilalihan tanggung jawab pembayaran oleh pihak lain (dalam hal ini diambil alih oleh Bank) atas dasar permintaan pihak yang dijamin (Applicant/Pembeli/Nasabah Bank) untuk melakukan pembayaran kepada pihak penerima jaminan (Beneficiary/Penjual) berdasarkan syarat dan kondisi yang ditentukan dan disepakati. Menurut Budisantoso (2006: 128), bahwa L/C juga biasa di sebut surat kredit berdokumen merupakan alat pembayaran yang di keluarkan bank atas permintaan importir dalam transaksi dagang internasional. Sementara menurut Ginting (2002: 15), secara umum L/C dalam pengertian bank konvensional di gunakan untuk membiayai sales contract jarak jauh antara pembeli dan penjual yang belum saling mengenal dengan baik. L/C berguna untuk menampung dan menyelesaikan kesulitan-kesulitan yang diemban pembeli (importir) maupun penjual (eksportir) dalam transaksi jual beli yang dilakukannya (Kasmir, 2002: 151).

Menurut ketentuan Uniform Customs and Practice for Documentary Credits (UCPDC 600), L/ C merupakan janji dari bank penerbit untuk melakukan pembayaran atau memberi kuasa kepada bank lain untuk melakukan pembayaran kepada penerima atas penyerahan dokumendokumen yang sesuai dengan persyaratan L/C. Inti dari pengertian L/C di sini adalah bahwa L/C merupakan “janji membayar” (Widjaja, 2001: 8). Sedangkan menurut Bank Indonesia, L/C merupakan janji dari issuing bank untuk membayar sejumlah uang kepada eksportir sepanjang ia dapat memenuhi syarat dan kondisi L/C tersebut (Bank Indonesia, 2008: C-1). Pengaturan hukum atas Letter of Credit tersebut diatur dalam perjanjian Internasional (bukan perjanjian Nasional/Indonesia) yang dikuti oleh semua Negara-negara 
ljtihad, Jurnal Wacana Hukum Islam dan Kemanusiaan, Volume 16, No.1, Juni 2016: 43-66

di dunia, yaitu menggunakan UCP 500 (United Custom Practice 500).

Terdapat berbagai macam Letter of Credit, antara lain: Pertama, Sight Letter of Credit yaitu alat bayar yang berupa surat kredit yang diterbitkan oleh Bank (Issuing Bank) dari pembeli di luar negeri (importir), bahwa pembayaran akan dilakukan sesuai dengan waktu yang telah ditentukan dalam Surat Kredit tersebut, dan L/C tersebut dapat di diskontokan oleh penjual di dalam negeri (eksportir) lewat bank di dalam negeri (Negotiating Bank) dengan cara melakukan collection yaitu penagihan pembayaran oleh Negotiating Bank kepada Issuing Bank.

Kedua, Usance Letter of Credit yaitu alat bayar yang berupa surat kredit yang diterbitkan oleh Bank (Issuing Bank) dari pembeli di luar negeri (importir), bahwa pembayaran akan dilakukan sesuai dengan waktu yang telah ditentukan dalam Surat Kredit tersebut, dan L/C tersebut dapat di diskontokan oleh Penjual di dalam negeri (Eksportir) lewat Bank didalam negeri (Negotiating Bank), dengan mengikuti semua persyaratan yang tercantum dalam L/C tersebut. Dalam Usance L/C, pendiskontoan dapat dilakukan apabila semua proses pengiriman telah dilakukan oleh Eksportir dan dokumen-dokumen inilah yang menyertai L/C tersebut untuk diserahkan ke Negotiating Bank, dalam rangka pendiskontoan L/C tersebut, dengan demikian segala Resiko pembayaran telah diambil alih oleh Negotiating Bank di dalam negeri.

Ketiga, Red Clause Letter of Credit yaitu alat bayar yang berupa surat kredit yang diterbitkan oleh Bank (Issuing Bank) dari pembeli di luar negeri (importir), yang berisi perintah pembayaran terlebih dahulu maksimal sebesar $80 \%$ dari issuing bank di luar negeri kepada negotiating bank di dalam negeri, di mana eksportir belum melakukan aktivitas ekspor sama sekali. L/ C ini merupakan pembayaran uang muka dari importir (down payment) kepada Eksportir. L/ C tersebut sangat likuid berlaku di perbankan, karena semua resiko telah ditanggung oleh bank penerbit di luar negeri dan pasti dibayar sesuai waktu yang telah ditentukan. Dalam Red Clause L/C, pendiskontoan 80\% dapat dilakukan oleh eksportir tanpa harus melakukan aktivitas ekspor terlebih dahulu, karena perlakuan dalam L/C tersebut adalah sangat khusus. Sehingga timbul kepercayaan yang tinggi dari importir kepada eksportir dan biasanya antara Bank kedua belah pihak telah melakukan korenpondensi terlebih dahulu. Sedangkan pelunasan 100\% akan dilakukan oleh negotiating bank, apabila eksportir telah selesai melakukan pengiriman ekspornya dengan menyerahkan dokumen-dokumen pengirimannya ke negotiating bank. 
Secara umum perlakuan verifikasi dari Letter of Credit adalah sama seperti Credit Card, yaitu penjual atau bank penjual melakukan verifikasi/authorifikasi kepada bank penerbit (issuing bank), sehingga penjual atau bank penjual dapat aman melakukan pembayaran terlebih dahulu kepada pemegang L/C atau pemegang kartu kredit tersebut. L/C dalam bank syariah termasuk produk pembiayaan, yaitu "pembiayaan Letter of Credit $(\mathrm{L} / \mathrm{C})$ impor atau ekspor syariah". Sebagaimana yang dikatakan oleh Karim (2008: 252), secara definitif yang dimaksud dengan $\mathrm{L} / \mathrm{C}$ adalah pembiayaan yang diberikan dalam rangka memfasilitasi transaksi impor atau ekspor nasabah.

L/C syariah terbagi menjadi 2 (dua), L/C impor syariah dan L/C ekspor syariah. Disebutkan dalam Kodifikasi Produk Perbankan Syariah yang dibuat oleh Bank Indonesia (BI), L/C impor syariah adalah surat pernyataan akan membayar kepada eksportir (beneficiary) yang diterbitkan oleh bank (issuing bank) atas permintaan importir dengan pemenuhan persyaratan tertentu sesuai dengan prinsip syariah (Fatwa DSN, 2003: 217). Sedangkan L/C ekspor syariah adalah surat pernyataan akan membayar kepada Eksportir yang diterbitkan oleh Bank untuk memfasilitasi perdagangan ekspor dengan pemenuhan persyaratan tertentu sesuai dengan prinsip syariah (Fatwa DSN, 2003: 228).

\section{Proses terbentuknya L/C syariah}

Menurut Totok Budisantoso (2006: 128), proses terjadinya L/C lebih disebabkan karena belum ada unsur kepercayaan antara eksportir dan importir. Bukan disebabkan karena terkait dengan cidera janji kedua belah pihak, baik penjual maupun pembeli, sebagaimana yang terjadi dalam kontrak bank garansi. Proses terbentuknya L/C dalam bank syariah sedikit banyak sama dengan proses terbentuknya L/C dalam bank konvensional. Hanya saja dalam proses terbentuknya L/C dalam bank syariah transaksinya harus sesuai dengan prinsipprinsip syariah itu sendiri.

Dilihat dari proses terjadinya L/C tersebut maka dapat dikatakan bahwa L/C juga merupakan pengalihan penanggungan risiko dari penjual dan pembeli yang kemudian diemban oleh pihak bank. Dari itu untuk mengantisipasi risiko yang diemban maka bank penerbit mewajibkan kepada importir untuk menyerahkan sejumlah uang sebagai jaminan sebesar 10\% dari nilai L/C, juga menyerahkan agunan tambahan dari importir (pemohon 
ljtihad, Jurnal Wacana Hukum Islam dan Kemanusiaan, Volume 16, No.1, Juni 2016: 43-66

L/C) (Budisantoso, 2006: 129).

Perjanjian dapat dilaksanakan apabila eksportir percaya bahwa bank penerbit L/C akan menempati janjinya. Janji dalam L/C tersebut pada prinsipnya adalah kesediaan bank penerbit L/C untuk membayar sejumlah uang pada saat penjual (eksportir) dapat menunjukkan bukti pengiriman barang serta dokumen pelengkapnya. Dengan demikian walaupun di dalam kontrak L/C ada suatu perjanjian, tetapi kontrak L/C bukanlah merupakan suatu perjanjian yang dapat berdiri sendiri. L/C lahir dari adanya perjanjian lain, biasanya jual beli barang jarak jauh antara penjual dan pembeli yang belum saling mengenal dengan baik, bahkan tidak pernah bertemu sebelumnya. Perjanjian atau kontrak inilah yang menjadi dasar proses terbentuknya $\mathrm{L} / \mathrm{C}$.

\section{Perjanjian penyelesaian sengketa $\mathrm{L} / \mathrm{C}$ ekspor-impor}

Kontrak secara etimologis (yang dalam bahasa Arab) diistilahkan dengan Mu'ahadab Ittifa atau Akad, dalam konsep fiqh mu'amalah istilah kontrak lebih dikenal dengan sebutan akad menurut istilah Fuqaha' (Shiddieqy, 1974: 10), dapat berarti:

$$
\text { ارتباط ايباب بقبول علي وجة مشروع يظهراثره في محله }
$$

"Akad ialah Perikatan ijab dengan qabul cara-cara yang disyariátkan yang mempunyai dampak pada yang diakadkan itu

Berdasarkan konteks tersebut, dalam akad terdapat beberapa unsur: yaitu adanya ijabqabul, berdasarkan cara-cara yang disyariatkan dan memilki dampak terhadap sesuatu yang dikadkan. Selain istilah tersebut menurut Black.s Law Dictionary (Black, 1968: 394) kontrak didefinisikan sebagai suatu kesepakatan yang diperjanjikan (promissory agreement) di antara dua atau lebih pihak yang dapat menimbulkan memodifikasi, atau menghilangkan hubungan hukum. Selanjutnya Steven H. Gifis (Setiawan, 2010: 138) memberikan pengertian kepada kontrak sebagai suatu perjanjian, atau seperangkat perjanjian dimana hukum memberikan ganti rugi terhadap wanprestasi terhadap kontrak tersebut, atau terhadap pelaksanaan kontrak tersebut oleh hukum dianggap sebagai suatu tugas.

Menyangkut apa yang telah diperkontrakan, masing-masing pihak haruslah menghormati terhadap apa yang telah mereka perjanjikan sebab di dalam ketentuan hukum yang terdapat 
dalam al-Quran antara lain dalam surat al-Maidah ayat 1:

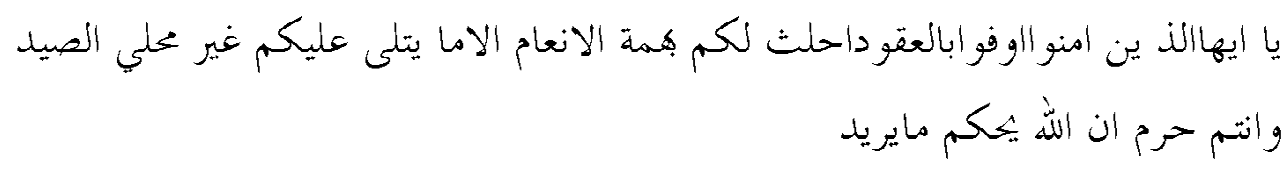

Hai orang-orang yang beriman, penuhilah aqad-aqad itu. Dihalalkan bagimu binatang ternak, kecuali yang akan dibacakan kepadamu. (Yang demikian itu) dengan tidak menghalalkan berburu ketika kamu sedang mengerjakan haji. Sesungguhnya Allah menetapkan hukum-hukum menurut yang dikehendaki-Nya.

Adapun yang dimaksud dengan akad atau kontrak adalah janji setia kepada Allah Swt., dan juga meliputi perjanjian yang dibuat oleh manusia dengan sesama dalam pergaulan hidupnya sehari-hari (Pasaribu, 1996: 2). Kontrak antara nasabah dan bank, pada umumnya mengikuti aturan sebagaimaa yang telah dipersyaratkan dalam hukum kontrak. Agar suatu kontrak oleh hukum dianggap sah sehingga mengikat kedua belah pihak, maka kontrak tersebut haruslah memenuhi syarat-syarat tertentu (Mukkaram, 2004: 437). Konsekuensi dari tidak terpenuhinya salah satu atau lebih dari syarat-syarat sahnya kontrak tersebut bervariasi mengikuti syarat mana yang dilanggar. Sehinggga jika terjadi sengketa konsekuensi hukumnya adalah sebagai berikut: 1) Batal demi hukum (nietig, null and void), misalnya dalam hal dilanggar syarat objektif diantaranya jika melanggar perihal tertentu dan kausa yang legal; 2) Dapat dibatalkan (vernietigbaar, voidable), misalnya tidak terpenuhinya syarat subjektif diantaranya kesepakatan kehendak dan kecakapan berbuat; 3) Kontrak tidak dapat dilaksanakan (unenforceable), kontrak yang tidak dapat dilaksanakan adalah kontrak yang tidak begitu saja batal tetapi tidak dapat dilaksanakan, melainkan masih mempunyai status hukum tertentu. Bedanya dengan kontrak yang batal (demi hukum) adalah bahwa kontrak yang tidak dapat dilaksanakan masih mungkin dikonversi menjadi kontrak yang sah. Sedangkan bedanya dengan kontrak yang dapat dibatalkan (viodable) adalah bahwa dalam kontrak yang dapat dibatalkan, kontrak tersebut sudah sah, mengikat dan dapat dilaksanakan sampai dengan dibatalkan kontrak tersebut, sementara kontrak yang tidak dapat dilaksankaan bukan mempunyai kekuatan hukum sebelum dikonversi menjadi kontrak yang sah (Fuady, 2001:34). 3) Sanksi administrasi, jika tidak terpenuhi syarat kontrak hanya mengakibatkan dikenakan sanksi administrasi saja 
ljtihad, Jurnal Wacana Hukum Islam dan Kemanusiaan, Volume 16, No.1, Juni 2016: 43-66

terhadap salah satu pihak atau kedua belah pihak dalam kontrak tersebut.

Dalam kontrak antara nasabah dengan bank dalam transaksi perbankan syariah, terdapat 8 (delapan) asas yang mendasari akad secara umum, yang harus dilindungi dan dijamin yaitu: (a) Rela sama rela (ridha’iyyab); (b) Manfaat bagi bank dan nasabah; (c) Keadilan dalam arti yang luas; (d) Saling menguntungkan; (e) Kebebasan berkontrak; (f) Kepastian hukum; (g) Itikad baik dalam berbisnis; dan (h) Tradisi ekonomi masyarakat.

Selain delapan asas tersebut, dalam lembaga keuangan syariah juga dikenal azas kebebasan berkontrak sebagaimana yang diatur dalam konsep-konsep hukum bisnis Islam (fiqh mu'amalah) yang meliputi: Pertama, Hukum kontrak bersifat hukum mengatur, artinya bahwa hukum tersebut baru berlaku sepanjang para pihak tidak mengaturnya lain. Jika para pihak dalam berkontrak mengaturnya secara lain dari yang diatur dalam hukum kontrak, maka yang berlaku adalah apa yang diatur sendiri oleh para pihak tersebut kecuali undang-undang menentukan lain. Kedua, azas kebebasan kontrak (freedom of contract). Artinya para pihak bebas membuat kontrak dan mengatur sendiri isi kontrak tersebut, sepanjang memenuhi ketentuan: (1) tidak dilarang oleh peraturan syari'at atau undang-undang; (2) sesuai dengan kebiasaan yang berlaku; (3) sepanjang kontrak tersebut dilaksanakan dengan itikad baik; Ketiga, azas janji mengikat (sunt servanda) bahwa suatu kontrak yang dibuat secara sah mempunyai ikatan hukum yang penuh; Keempat, asas konsensua, bahwa suatu kontrak sudah sah dan mengikat ketika tercapai Kelima, asas kontrak bersifat obligator, maksudnya adalah setelah sahnya suatu kontrak, maka kontrak tersebut sudah mengikat, tetapi baru sebatas menimbulkan hak dan kewajiban di antara para pihak. Keenam, azas jelas dan gamblang, bahwa apa yang dikontrakan oleh para pihak harus terang sehingga tidak mengakibatkan terjadinya kesalahpahaman atau terdapat jangan sampai terjadi multitafsir di antara para pihak tentang apa yang telah mereka sepakati di kemudian hari. Pada dasarnya setiap kontrak yang dibuat dalam lembaga keuangan syariah disyaratkan harus dibuat dalam bentuk tertulis, atau bahkan harus dibuat oleh atau di hadapan pejabat tertentu (juru tulis, katib), sehingga disebut dengan kontrak formal.

Berdasarkan Fatwa No.34/DSN-MUI/IX/2002, ketentuan akad-akad untuk Letter of Credit (L/C) Impor yang sesuai dengan syariah dapat digunakan beberapa bentuk: Pertama, Akad wakalah bi al-ujrah, dengan ketentuan: (1) Importir harus memiliki dana pada bank 
sebesar harga pembayaran barang yang diimpor; (2) Importir dan Bank melakukan akad wakalah bi al-ujrah untuk pengurusan dokumen-dokumen transaksi impor; (3) Besar ujrah harus disepakati di awal dan dinyatakan dalam bentuk nominal, bukan dalam bentuk prosentase.

Kedua, akad wakalah bi al-ujrah dan qard, dengan ketentuan: (1) Importir tidak memiliki dana cukup pada bank untuk pembayaran harga barang yang diimpor; (2) b. Importir dan Bank melakukan akad wakalah bi al-ujrah untuk pengurusan dokumen-dokumen transaksi impor; (3) Besar ujrah harus disepakati di awal dan dinyatakan dalam bentuk nominal, bukan dalam bentuk prosentase; (4) Bank memberikan dana talangan (qard) kepada importir untuk pelunasan pembayaran barang impor.

Ketiga, Akad Murabahah dengan ketentuan: (1) Bank bertindak selaku pembeli yang mewakilkan kepada importir untuk melakukan transaksi dengan eksportir; (2) Pengurusan dokumen dan pembayaran dilakukan oleh bank saat dokumen diterima (at sight) dan/atau tangguh sampai dengan jatuh tempo (usance); (3) Bank menjual barang secara murabahah kepada importir, baik dengan pembayaran tunai maupun cicilan; (4) Biaya-biaya yang dikeluarkan oleh bank akan diperhitungkan sebagai harga perolehan barang.

Keempat, Akad Salam/Istisna' dan Murabahah, dengan ketentuan: (1) Bank melakukan akad Salam atau Istishna' dengan mewakilkan kepada importir untuk melakukan transaksi tersebut. (2) Pengurusan dokumen dan pembayaran dilakukan oleh bank; (3) Bank menjual barang secara murabahah kepada importir, baik dengan pembayaran tunai maupun cicilan; (4) Biaya-biaya yang dikeluarkan oleh bank akan diperhitungkan sebagai harga perolehan barang.

Kelima, Akad wakalah bi al-ujrah dan mudarabah, dengan ketentuan: (1) Nasabah melakukan akad wakalah bi al-ujrah kepada bank untuk melakukan pengurusan dokumen dan pembayaran; (2) Bank dan importir melakukan akad Mudharabah, dimana bank bertindak selaku shahibul mal menyerahkan modal kepada importir sebesar harga barang yang diimpor.

Keenam, Akad musharakah, dengan ketentuan Bank dan importir melakukan akad musharakah, dimana keduanya menyertakan modal untuk melakukan kegiatan impor barang.

Ketujuh, Dalam hal pengiriman barang telah terjadi, sedangkan pembayaran belum dilakukan, akad yang digunakan adalah: Alternatif I : wakalah bi al-ujrah dan qard, dengan ketentuan: (1) Importir tidak memiliki dana cukup pada bank untuk pembayaran harga 
ljtihad, Jurnal Wacana Hukum Islam dan Kemanusiaan, Volume 16, No.1, Juni 2016: 43-66

barang yang diimpor; (2) Importir dan Bank melakukan akad wakalah bi al-ujrah untuk pengurusan dokumen-dokumen transaksi impor; (3) Besar ujrah harus disepakati di awal dan dinyatakan dalam bentuk nominal, bukan dalam bentuk prosentase; (4) Bank memberikan dana talangan (qard) kepada nasabah untuk pelunasan pembayaran barang impor. Alternatif II: wakalab bi al-ujrah dan haw alah, dengan ketentuan: (1) Importir tidak memiliki dana cukup pada bank untuk pembayaran harga barang yang diimpor; (2) Importir dan Bank melakukan akad wakalah untuk pengurusan dokumen-dokumen transaksi impor; (3) Besar ujrah harus disepakati di awal dan dinyatakan dalam bentuk nominal, bukan dalam bentuk prosentase; dan (4) Hutang kepada eksportir dialihkan oleh importir menjadi hutang kepada Bank dengan meminta bank membayar kepada eksportir senilai barang yang diimpor (Fatwa DSN, 2003: 218).

Sedangkan dalam Fatwa No. 35/DSN-MUI/IX/2002, ketentuan akad-akad untuk Letter of Credit (L/C) Ekspor yang sesuai dengan syariah dapat berupa: Pertama, Akad wakalah bi al-ıjrah, dengan ketentuan: (1) Bank melakukan pengurusan dokumen-dokumen ekspor; (2) Bank melakukan penagihan (collection) kepada bank penerbit L/C (issuing bank), selanjutnya dibayarkan kepada eksportir setelah dikurangi ujrab; (3) Besar ujrab harus disepakati di awal dan dinyatakan dalam bentuk nominal, bukan dalam bentuk prosentase.

Kedua, akad wakalah bi al-ujrah dan qard, dengan ketentuan: (1) Bank melakukan pengurusan dokumen-dokumen ekspor; (2) Bank melakukan penagihan (collection) kepada bank penerbit L/C (issuing bank); (3) Bank memberikan dana talangan (qard) kepada nasabah eksportir sebesar harga barang ekspor; (4) Besar ujrah harus disepakati di awal dan dinyatakan dalam bentuk nominal, bukan dalam bentuk prosentase; (5) Pembayaran ujrah dapat diambil dari dana talangan sesuai kesepakatan dalam akad; dan (6) Antara akad wakalah bi al-ujrah dan akad qard, tidak dibolehkan adanya keterkaitan (ta'alluq).

Ketiga, Akad wakalah bi al-ujrah dan mudarabah, dengan ketentuan: (1) Bank memberikan kepada eksportir seluruh dana yang dibutuhkan dalam proses produksi barang ekspor yang dipesan oleh importir; (2) Bank melakukan pengurusan dokumen-dokumen ekspor; (3) Bank melakukan penagihan (collection) kepada bank L/C (issuing bank). (4) Pembayaran oleh bank penerbit L/C dapat dilakukan pada saat dokumen diterima (at sight) atau pada saat jatuh tempo (usance); (5) Pembayaran dari bank penerbit L/C (issuing bank) dapat digunakan 
untuk: pembayaran ujrah, pengembalian dana mudharabah, dan pembayaran bagi hasil; dan (6) Besar ujrah harus disepakati di awal dan dinyatakan dalam bentuk nominal, bukan dalam bentuk prosentase.

Keempat, akad musharakah, dengan ketentuan: (1) Bank memberikan kepada eksportir sebagian dana yang dibutuhkan dalam proses produksi barang ekspor yang dipesan oleh importir; (2) Bank melakukan pengurusan dokumen-dokumen ekspor; (3) Bank melakukan penagihan (collection) kepada bank penerbit L/C (issuing bank); (4) Pembayaran oleh bank penerbit L/C dapat dilakukan pada saat dokumen diterima (sigbt) atau pada saat jatuh tempo (usance); dan (5) Pembayaran dari bank penerbit L/C (issuing bank) dapat digunakan untuk: pengembalian dana musharakah, dan pembayaran bagi hasil.

Kelima, Akad al-Bai' (Jual Beli) dan wakalah, dengan ketentuan: (1) Bank membeli barang dari eksportir; (2) Bank menjual barang kepada importir yang diwakili eksportir; (3) Bank membayar kepada eksportir setelah pengiriman barang kepada importir; dan (4) Pembayaran oleh bank penerbit L/C (issuing bank) dapat dilakukan pada saat dokumen diterima (at sight) atau pada saat jatuh tempo.

Penegasan adanya prinsip syariah dalam Undang-Undang Nomor 10 Tahun 1998 merupakan salah satu yang membedakan antara bank konvensional dengan bank syariah. Perbedaan lain yang menonjol adalah mengenai penyelesaian sengketa. Dalam perjalanan sejarah penyelesaian sengketa bank syariah, setidaknya ada 3 (tiga) lembaga yang mempunyai kompetensi untuk menanganinya yaitu arbitrase, peradilan umum dan peradilan agama. Dua lembaga terakhir merupakan lembaga peradilan yang seringkali disebut dengan litigasi, sedangkan satu lembaga lain adalah proses di luar pengadilan (non litigasi).

Kewenangan arbitrase menyelesaikan perbankan syariah dapat didasarkan atas kesepakatan ketika membuat perjanjian pactum de compromittendo atau dibuat ketika terjadi sengketa akta kompromis (Ngatino, 1999: 21). Penyelesaian sengketa melalui arbitrase sering sekali dilakukan dalam dunia bisnis (termasuk dunia perbankan). Pilihan ini lebih disebabkan banyaknya kelebihan arbitrase dibandingkan proses litigasi (Harahap, 1994: 20).

Proses hukum yang memerlukan waktu panjang, biasanya dijadikan alasan utama dalam memilih arbitrase disamping penyelesaian arbitrase yang bersifat win win solution dan tidak menempatkan para pihak sebagai lawan. Penanganan sengketa syariah oleh badan arbitrase 
ljtihad, Jurnal Wacana Hukum Islam dan Kemanusiaan, Volume 16, No.1, Juni 2016: 43-66

telah dirintis oleh BAMUI (Badan Arbitrase Mualamat Indonesia) yang dibentuk pada tahun 1993 untuk menyelesaikan sengketa bidang mu'amalat (Dewi, 2005: 183; Dimyati, 1994: 191). Dalam perkembangannya BAMUI kemudian menjadi cikal bakal BASYARNAS (Badan Arbitrase Syariah Nasional) (Jauhari, 2004: 15).

Selain arbitrase, peradilan umum berwenang menyelesaikan sengketa perbankan syariah berdasarkan Pasal 50 Undang-Undang Nomor 8 Tahun 2004 Tentang Perubahan Atas Undang-Undang Nomor 2 Tahun 1986 Tentang Peradilan Umum yang menyebutkan bahwa Pengadilan Negeri bertugas dan berwenang memeriksa, memutus dan menyelesaikan perkara pidana dan perkara perdata di tingkat pertama. Sejak lahirnya perbankan syariah (kelahiran Bank Mu'alamat Indonesia tahun 1991), peradilan umum mempunyai kewenangan untuk menyelesaikan sengketa perbankan syariah, namun sejak tahun 2006 penyelesaian sengketa perbankan syariah beralih menjadi kewenangan Pengadilan Agama berdasarkan UndangUndang Nomor 3 Tahun 2006 Tentang Perubahan Atas Undang-Undang Nomor 7 Tahun 1989 Tentang Peradilan Agama (Mahir, 2012: 355).

Berdasarkan Pasal 49 Undang-Undang tersebut Pengadilan Agama bertugas dan berwenang, memeriksa, memutus dan menyelesaikan perkara ditingkat pertama antara orang-orang yang beragama Islam di bidang: (1) Perkawinan; (2) Waris, (3) Wasiat, (4) Hibah, (5) Wakaf, (6) Zakat, (7) Infaq, (8) Shadaqah, dan (9) Ekonomi syariah (Katuconsina, 2008: 126; Sugiswati, 1998: 53)

Dalam Penjelasan Pasal 49 huruf i mengenai ekonomi syariah mencakup 11 termasuk di dalamnya bank syariah. Sejak lahirnya Undang-Undang Nomor 3 Tahun 2006 jo. UndangUndang Nomor 7 Tahun 1989 Tentang Peradilan Agama maka berdasarkan asas hukum lex spesialis derogat lex generalis (Mahir, 2012: 356). Pengadilan Negeri sudah tidak berwenang lagi menyelesaikan sengketa ekonomi syariah.

Namun demikian dalam sengketa yang berkaitan dengan hak milik atau sengketa keperdataan lain antara orang-orang yang beragama Islam dan non Islam mengenai sengketa sebagaimana dimaksud dalam Pasal 49 Undang-Undang Nomor 3 Tahun 2006 sangat terkait dengan peradilan umum (Anshori, 2006: 45). Hal ini ditegaskan pada Pasal 50 UndangUndang Nomor 3 Tahun 2006 jo. Undang-Undang Nomor 7 Tahun 1989 ayat (1) dari Pasal 50 menegaskan tentang kewenangan Peradilan Umum manakala terjadi sengketa 
kepemilikan atas obyek dari pasal 49. Sedangkan ayat (2) merupakan pembahasan eksepsionalnya, di mana ketika para pihak yang bersengketa adalah orang-orang yang beragama Islam, maka sengketa kepemilikan tersebut diselesaikan bersama-sama dengan sengketa yang terdapat pada Pasal 49.

Setelah lahirnya Undang-Undang Perbankan Syariah selain Pengadilan Agama yaitu Pengadilan Negeri dan Arbitrase mempunyai peluang yang sama dalam menyelesaian sengketa syariah. Pasal 55 Undang-Undang Perbankan Syariah berbunyi: (1) Penyelesaian sengketa Perbankan Syariah dilakukan oleh pengadilan dalam ingkungan Peradilan Agama. (2) Dalam hal para pihak telah memperjanjikan penyelesaian sengketa selain sebagaimana dimaksud pada ayat (1), penyelesaian sengketa dilakukan sesuai dengan isi akad. (3) Penyelesaian sengketa sebagaimana dimaksud pada ayat (2) tidak boleh bertentangan dengan Prinsip Syariah.

Penjelasan dari ayat (2) diatas menyebutkan bahwa pihak yang berwenang menyelesaikan sengketa sesuai dengan isi akad adalah upaya dengan musyawarah, mediasi perbankan, badan arbitrase Syariah Nasional atau lembaga arbitrase lain serta melalui pengadilan dalam lingkungan peradilan umum. Hal ini secara materil substansial Pasal 55 Undang-Undang Perbankan Syariah telah memunculkan kembali kompetensi absolute peradilan umum terhadap sengketa ekonomi syariah yang sebelumnya telah dilimpahkan kepada peradilan agama.

Penyelesaian sengketa selain melalui peradilan agama (mediasi, arbitrase dan peradilan umum) sangat tergantung terhadap kontrak yang dibuat ketika nasabah dan bank melakukan transaksi perbankan. Seperti halnya dalam sengketa perbankan konvensional, penangannya sangat tergantung kepada kontrak yang dibuat, namun dalam penanganan sengketa perbankan syariah terdapat perbedaan baik secara formil maupun materil.

Perbedaan secara formil, Pengadilan Agama mempunyai kewenangan terhadap penanganan sengketa ekonomi syariah berdasarkan Undang-Undang Peradilan Agama yaitu Undang-Undang Nomor Nomor 3 Tahun 2006 jo. Undang-Undang Nomor 7 Tahun 1989, sedangkan Pengadilan Negeri mempunyai kewenangan menyelesaikan sengketa syariah berdasarkan pada akad yang dibuat saat transaksi perbankan. Adapun kewenangan yang diberikan oleh Undang-Undang Peradilan Umum yaitu Undang-Undang Nomor Nomor 8 Tahun 2004 jo. Undang-Undang Nomor 2 Tahun 1986 telah dinasakh oleh UndangUndang Peradilan Agama. Dari sisi materil kewenangan Pengadilan Agama ditentukan 
ljtihad, Jurnal Wacana Hukum Islam dan Kemanusiaan, Volume 16, No.1, Juni 2016: 43-66

langsung oleh Undang-Undang Perbankan Syariah, sesuatu yang berbeda yang tidak pernah terjadi pada Pengadilan Negeri, sebab meskipun Pengadilan Negeri berwenang menyelesaikan sengketa perbankan konvensional dan pernah berwenang menyelesaikan sengketa syariah hanya ditetapkan berdasarkan Undang-Undang Peradilan Umum, bukan berdasarkan Undang-Undang Perbankan (Junaidy, 2004: 544).

Untuk menjembatani adanya perbedaan hukum yang berlaku dalam perjanjian antara nasabah dan bank syariah apakah KUHPerdata sebagai hukum positif yang diakui di Indonesia atau hukum Islam. Sjahdeini (2002: 135) mengemukakan bahwa selain asas kebebasan berkontrak dalam Pasal 1338 KUHPerdata, terdapat asas lain yang harus diperhatikan dalam hukum perjanjian. Asas tersebut menentukan bahwa apabila di dalam perjanjian tidak diatur mengenai hal yang dipermasalahkan oleh para pihak, tetapi hal itu telah diatur oleh hukum perjanjian dalam KUHPerdata, maka ketentuan dalam KUHPerdata itu yang diberlakukan. Namun jika hal tersebut telah diatur dalam perjanjian, tetapi isinya berbeda dengan pengaturan dalam KUHPerdata, maka yang harus diberlakukan adalah ketentuan dalam perjanjian itu dengan ketentuan sepanjang pengaturan dalam hukum perjanjian tidak merupakan ketentuan yang tidak boleh disimpangi (ketentuan tersebut bersifat memaksa atau dwingendrecbt). Isi perjanjian tidak boleh bertentangan dengan undang-undang ketentuan dari hukum perjanjian itu harus diberlakukan, sedangkan ketentuan-ketentuan dari perjanjian itu batal demi hukum. Selanjutnya Sjachdeini (2002: 136) mengemukakan, bahwa sebagian besar ketentuan hukum perjanjian dalam KUHPerdata bersifat tidak memaksa (aanvullend recht), artinya, boleh disimpangi oleh para pihak dengan membuat ketentuan-ketentuan dan syarat-syarat lain di dalam perjanjian yang dibuat oleh mereka.

Kebebasan untuk memilih termasuk "kebebasan untuk berkontrak" bagi setiap individu selain bersifat kudrati dan hak paling asasi serta merupakan bagian dari pengertian yang lebih luas dari definisi "ibadah mu'amalah" (Mugiyati, 2012: 274), maka dalam hubungan dengan negara, juga mendapat jaminan dalam Undang-Undang Dasar 1945 Pasal 29 yakni, "negara menjamin kemerdekaan tiap-tiap penduduk untuk memeluk agamanya masingmasing dan untuk beribadat menurut agamanya dan kepercayaannya itu". Dengan demikian jaminan UUD 1945 ini harus dipandang sebagai adanya kebebasan bagi kaum muslimin untuk melakukan aktivitas keperdataan sesuai dengan konsep syariah Islam sebagai keyakinan 
yang dianutnya.

Demikian pula dalam hubungan jual beli antara importir dan eksportir, juga termasuk kontrak internasional, mengingat kedua belah pihak berada dalam wilayah negara yang berbeda. Dalam hal ini, jika terjadi sengketa diantara mereka, penyelesaian hukum yang digunakan dapat mengunakan prinsip-prinsip penyelesaian sengketa perdata internasional. Dalam penyelesaian sengketa perdata internasional, pada umunya para pihak diberi kebebasan untuk menentukan sendiri forum dan hukum yang dapat mereka gunakan untuk menyelesaikan sengketa yang dapat timbul dalam pelaksanaan transaksi tersebut sepanjang tidak bertentangan dengan hukum, kesusilaan, dan ketertiban umum di masing-masing dinegara yang berlaku.

Jika dalam kontrak perdata internasional tidak dicantumkan pilihan forum maupun pilihan hukumnya, Hukum Perdata Internasional memberikan beberapa teori mengenai cara-cara penyelesaian sengketanya sebagai berikut: Pertama, Teori Lex Loci Contractus; yaitu hukum suatu kontrak ditentukan oleh hukum dimana kontrak itu dibuat. Namun dalam perkembangan praktek dagang internasional hal ini ada kesulitan untuk menentukan tempat jika para pihak yang melangsungkan suatu kontrak tidak bertemu muka secara langsung (Gautama, 1998: 12-13). Sebagai contoh dalam aplikasi penerbitan L/C, hal ini dapat terjadi jika para pihak membuat kesepakatan tidak bertemu secara langsung, tetpi menggunakan melalui media elektronik, misalnya dengan menggunakan media internet. Kedua, Teori Lex Loci Solutionis; yaitu hukum yang berlaku atas suatu kontrak didasarkan pada tempat di mana perjanjian itu dilaksanakan. Pada umumnya memang lazim dalam kontrak-kontrak dagang internasional, sesuai dengan praktek perdagangan yang menjadi kebiasaan, bahwa ditentukan tempat penyerahan barang-barang bersangkutan atau di mana jasa-jasa yang harus diberikan akan diterima. Namun teori ini juga dapat menimbulkan kesulitan jika ada beberapa tempat pelaksanaan kontrak tersebut (Gautama, 16-17). Dalam hubungannya dengan praktek penerbitan L/C, tampaknya juga ada kesulitan mengingat penerbitan L/C melibatkan tempat wilayah yang berbeda antara Negara importir dan eksportir. Ketiga, The Proper Law of the Contract ; yaitu hukum yang berlaku atas suatu kontrak berdasarkan "intention of the parties" yakni maksud para pihak dengan melihat fakta-fakta yang secara tidak langsung menunjukan keinginan para pihak untuk memberlakukan suatu hukum tertentu. Keempat, The Most Char- 
ljtihad, Jurnal Wacana Hukum Islam dan Kemanusiaan, Volume 16, No.1, Juni 2016: 43-66

acteristic Connection; yaitu hukum yang berlaku atas sutau kontrak adalah tergantung prestasi siapa yang paling karakteristik atau paling dominan (Lita, 2011). Sebagai contoh dalam transaksi jual beli, kepentingan penjual dianggap sebagai prestasi paling dominan dalam menentukan hukum yang berlaku dalam kontrak. Dalam aplikasi L/C dianggap hukum dari pihak beneficiary/eksportir dianggap paling dominan.

Banyaknya pilihan forum (choice of forum) yang dibuka oleh ketentuan Pasal 55 ayat (2) Undang-Undang Nomor 21 Tahun 2008 dan penjelasannya dalam realita menimbulkan conflict of dispute settlement (pertentangan mengenai lembaga penyelesaian sengketa) ini sudah belasan atau malah puluhan kali terjadi baik antara Basyarnas dengan Pengadilan Negeri atau antara Basyarnas dengan Pengadilan Agama atau antara Pengadilan Agama dengan Pengadilan Negeri, yang mungkin muncul karena tidak terpenuhinya kepentingan (keinginan) para pihak atau hasil dari penafsiran masing-masing pihak terhadap ketentuan Pasal 55 ayat (2) UndangUndang Nomor 21 Tahun 2008 dan penjelasannya. Mensikapi permasalahan tersebut Mahkamah Konstitusi dalam Putusan Nomor 93/PUU-X/2012, memberikan amar putusan: 1. Penjelasan Pasal 55 ayat (2) Undang-Undang Nomor 21 Tahun 2008 tentang Perbankan Syariah (Lembaran Negara Republik Indonesia Tahun 2008 Nomor 94, Tambahan Lembaran Negara Republik Indonesia Nomor4867) bertentangan dengan UndangUndang Dasar Negara Republik Indonesia Tahun 1945;

2. Penjelasan Pasal 55 ayat (2) Undang-Undang Nomor 21 Tahun 2008 tentang Perbankan Syariah (Lembaran Negara Republik Indonesia Tahun2008 Nomor 94, Tambahan Lembaran Negara Republik Indonesia Nomor4867) tidak mempunyai kekuatan hukum mengikat;

Amar putusan Mahkamah tersebut melahirkan norma baru dan jaminan kepastian hukum dalam hal penyelesaian sengketa perbankan syariah, yaitu: Pertama, pilihan forum penyelesaian sengketa yang dibuka oleh penjelasan Pasal 55 ayat (2) Undang-Undang Nomor 21 Tahun 2008 tentang Perbankan Syariah dalam beberapa kasus konkret telah nyata menimbulkan ketidakpastian hukum yang dapat merugikan bukan hanya nasabah tetapi juga pihak bank yang pada akhirnya akan menyebabkan adanya tumpang tindih kewenangan untuk mengadili karena ada dua peradilan yang diberikan kewenangan untuk menyelesaikan sengketa perbankan syariah. Kedua, pada prinsipnya dalam sengketa perbankan syariah pihak-pihak 
yang bersengketa diberi kebebasan untuk menentukan mekanisme penyelesaian sengketa yang dikehendaki sesuai prinsip syariah atau hukum Islam yang termuat dalam kesepakatan tertulis antara Bank Syariah dengan pihak lain (nasabah) yang memuat adanya hak dan kewajiban bagi masing-masing pihak yang selanjutnya kesepakatan tertulis ini dituangkan dalam bentuk akad. Ketiga, secara sistematis pilihan forum hukum sesuai dengan akad adalah pilihan kedua jika para pihak tidak sepakat menyelesaikan sengketa melalui Pengadilan Agama. Dengan demikian pilihan forum hukum untuk menyelesaikan sengketa perbankan syariah harus secara jelas tercantum di dalam akad (perjanjian).

Berdasarkan amar putusan Mahkamah Konstitusi kesimpulan yang bisa ditarik yang menimbulkan implikasi hukum dalam penyelesaian sengketa perbankan syariah, antara lain:

1. Penyelesaian sengketa perbankan syariah secara litigasi merupakan kewenagan absolut (mutlak) pengadilan dalam lingkungan Peradilan Agama;

2. Penyelesaian sengketa perbankan syariah secara non-litigasi tergantung para pihak yang melakukan akad dalam aktifitas perbankan syariah dapat membuat pilihan forum hukum (choice of forum) jika para pihak tidak bersepakat untuk menyelesaian sengketa melalui Peradilan Agama selama tidak boleh bertentangan dengan prinsip syariah;

3. Walaupun para pihak dalam membuat akad (perjanjian) mempunyai asas kebebasan berkontrak (freedom of making contract) dan menjadi Undang-Undang bagi mereka yang membuatnya (asas pacta sunt servanda), namun suatu akad tidak boleh bertentangan dengan Undang-Undang yang telah menetapkan adanya kekuasaan (kewenangan) mutlak (absolut) bagi suatu badan peradilan untuk menyelesaikan sengketa,

4. Penyelesaian sengketa Perbankan Syariah secara litigasi menjadi kewenangan absolut Pengadilan dalam lingkungan Peradilan Agama, karena para pihak tidak boleh memperjanjikan lain akibat terikat dengan Undang-Undang yang telah menetapkan adanya kekuasaan (kewenangan) mutlak (absolut) bagi suatu badan peradilan untuk menyelesaikan sengketa namun secara non litigasi para pihak dibebaskan untuk membuat pilihan forum penyelesaian sengketa (settlement dispute option), termasuk menyelesaikan sengketanya melalui Badan Arbitrase Syariah Nasional yang putusannya bersifat final dan binding.

5. Para pihak dalam menyelsaikan sengketa perbankan syariah secara non-litigasi tidak hanya tergantung pada penyelesaian secara musyawarah, mediasi perbankan, arbitrase melalui 
ljtihad, Jurnal Wacana Hukum Islam dan Kemanusiaan, Volume 16, No.1, Juni 2016: 43-66

Badan Arbitrase Syariah Nasional atau lembaga arbitrase lainnya, tetapi dapat juga menempuh proses non-litigasi lainnya seperti konsultasi, negosiasi (perundingan), konsultasi, mediasi dan non mediasi perbankan, pendapat atau penilaian ahli.

\section{Penutup}

Berdasarkan hasil penelitian dan analisis pembahasan, maka dapat disimpulkan: Pertama, kedudukan Letter of Credit sebagai transaksi antar negara dalam perbankan syariah, tidak hanya diatur dalam hukum perjanjian Nasional tetapi juga diatur dalam perjanjian Internasional dengan ketentuan tidak betentangan dengan prinsip syariah. Kedua, dalam hal terjadi permasalahan penyelesaian sengketa bank syariah menurut Putusan Mahkamah Konstitusi Nomor 93/PUU-X/2012 dapat menggunakan 2 (dua) yaitu litigasi dan non litigasi. Jalur litigasi menjadi kewenangan absolut peradilan agama, sedangkan jalur non-litigasi para pihak dapat melakukan pilihan tidak sekedar sebagaimana ditentukan dalam Penjelasan Pasal 55 ayat (2) Undang-Undang Nomor 21 Tahun 2008 tentang Perbankan Syariah tetapi dapat juga menempuh alternatif lain sesuai dengan akad yang telah disepakati.

\section{Daftar pustaka}

Adisasmita, Tjarsim. Menangani Transaksi Ekspor Berdasarkan Letter of Credit. Jakarta: Puja Almasar Lestari Consultant (Palcoms), 2007.

Anshori, Abdul Ghofur. Pokok-Pokok Hukum Perjanjian Islam di Indonesia. Yogyakarta: Citra Media, 2006.

Ash Shiddieqy, T.M. Hasbi. Pengantar Figh Mu.amalah. Jakarta: Bulan Bintang, 1974.

Bank Indonesia. Kodifikasi Produk Perbankan Syariah. Jakarta: Direktorat Perbankan Syariah Bank Indonesia, 2008.

Basri, Ikhwan Abidin. "Sistem Keuangan Islam Sebuah Alternatif”, dalam Republika Online, 20 November 2001.

Black, Henry Campbel. Black's Law Dictionary. USA: West Publishing Co, 1968.

Budisantoso, Totok. Bank dan Lembaga Kenangan Lainnya. Jakarta: Salemba Empat, 2006.

Dewi, Gemala., dkk. Hukum Perikatan Islam di Indonesia. Jakarta: Kencana, 2005.

Dimyati, Achmad. "Sejarah Lahirnya BAMUI". dalam Tim Editor, Arbitrase Islam di Indonesia, Jakarta: BMI, 1994.

Fatwa Dewan Syariah Nasional Majelis Ulama Indonesia (DSN MUI) Nomor 34/DSN- 
MUI/IX/2002 tentang Letter of Credit (L/C) Impor Syariah.

Fuady, Munir. Hukum Kontrak: Dari Sudut Pandang Hukum Bisnis. Bandung: PT. Citra Aditya Bakti, 2001.

Gautama, Sudargo. Hukum Perdata Internasional Indonesia. Bandung: Penerbit Alumni, 1998.

Ginting, Ramlan. Letter of Credit: Tinjauan Aspek Hukum dan Bisnis. Jakarta: Salemba Empat, 2002.

Gumansyah, Wery. "Penyelesaian Sengketa Perbankan Syariah Menurut Undang-Undang Nomor 21 Tahun 2008," dalam Jurnal Mizani, Vol. 2, No. 2: Agustus 2014.

Hadjon, Philipus M. "Pengkajian Ilmu Hukum Dogmatik," dalam Hukum Yiridika No. 6 Th. IX, Nov-Des 1994.

Harahap, M. Yahya. Alternatif Penyelesaian Sengketa. Jakarta: Sinar Grafika, 1994.

Hinkelman, Edward G. Metode Pembayaran Bisnis Internasional, Penerjemah Hesti Widyadiningrum. Jakarta: Penerbit PPM, 2002.

Jauhari, Achmad. Badan Arbitrase Syariah dan Peranannya dalam Mendukung Pengembangan Lembaga Kenangan Syariah. Jakarta: BASYARNAS, 2004.

Junaidy, Abdul Basith. "Bank Syariah dalam Hukum Perbankan Indonesia," dalam Jurnal Pemikiran dan Pembaharuan Hukum Islam al-Qanun Vol. 8, No. 2, Desember 2004.

Karim, Adiwarman A. Bank Islam: Analisis Fiqh dan Keuangan. Jakarta: RajaGrafindo Persada, 2008.

Kasmir. Bank dan Lembaga Keuangan Lainnya. Jakarta: RajaGrafindo Persada, 2002.

Latuconsina, Abd. Khalik. "Hukum Islam dan Eksistensi Peradilan Agama di Indonesia; Studi Pendekatan Sosiohistoris," dalam Reformasi Hukum Vol. XI No. 2, Desember 2008.

Lita, Helza Nova. "Penyelesaian Sengketa Dalam Transaksi Perbankan Syariah," dalam www.helzablogspot.com/Penyelesaian_Sengketa_Dala Transaksi_Perbankan_Syariah.html. Diakses, 1 Pebruari 2011.

Mugiyati. "Aplikasi Kafalah pada Asuransi Takaful Perspektif Akad Bisnis Islam," dalam Hukum Bisnis Islam Vol. 02, No. 01, Juni 2012.

Mahir. "Kewenangan Pengadilan Agama dalam Sengketa Perbankan Syariah," dalam Hukum Bisnis Islam Vol. 02, No. 01, Juni 2012.

Mahmassani, Sobhi. Filsafat Hukum Dalam Islam. Bandung: Al-Ma'arif, 1981.

Mukkaram, Akh. 2004. "Prinsip-prinsip Syar'i tentang Perikatan dalam KUH Perdata Indonesia dan Undang-Undang Perdata Maroko," dalam Jurnal Pemikiran dan Pembaharuan Hukum Islam al-Qanun Vol. 8, No. 2, Desember 2004. 
ljtihad, Jurnal Wacana Hukum Islam dan Kemanusiaan, Volume 16, No.1, Juni 2016: 43-66

Ngatino. Arbitrase. Jakarta: STIH IBLAM, 1999.

Pasaribu, Chairuman dan Suhrawardi K. Lubis. Hukum Perjanjian Dalam Islam. Jakarta: Sinar Grafika, 1996.

Peraturan Pemerintah Nomor 70 tahun 1992 Tentang Perubahan Lembaga Keuangan Bukan Bank (LKBB) Menjadi Bank Umum.

Putusan Mahkamah Konstitusi Nomor 93/PUU-X/2012 tentang Uji Materiil UndangUndang Nomor 8 Tahun 2010 tentang Perbankan terhadap UUD NRI 1945.

Setiawan, Wijayanto. "Aspek Hukum Kontrak Dagang via Internet (Cyberspace transaction) dalam Perspektif Sistem Hukum Islam," dalam Jurnal Wacana Hukum Islam dan Kemanusiaan Ijtihad, Vol. 10, No. 2, Desember 2010.

Sjachdeini, Sutan Remy. Perbankan Islam dan Kedudukannya dalam Tata Hukum Perbankan Indonesia. Jakarta: RajaGrafindo Persada, 2002.

Sugiswati, Besse. "Kewenangan Pengadilan Agama setelah Berlakunya Undang-Undang Nomor 7 Tahun 1998," dalam Kajian Masalab Hukum dan Pembangunan Perspektif, Vol. 3, No. 1, Januari-Maret 1998.

Undang-Undang Nomor 2 Tahun 1986 Tentang Peradilan Umum.

Undang-Undang Nomor 7 Tahun 1989 Tentang Peradilan Agama.

Undang-Undang Nomor 7 Tahun 1992 tentang Perbankan.

Undang-Undang Nomor 10 Tahun 1998 Tentang Perubahan Atas Undang-undang Nomor 7 Tahun 1992 Tentang Perbankan.

Undang-Undang Nomor 8 Tahun 2004 Tentang Perubahan Atas Undang-Undang Nomor 2 Tahun 1986 Tentang Peradilan Umum.

Undang-Undang Nomor 3 Tahun 2006 Tentang Perubahan Atas Undang-Undang Nomor 7 Tahun 1989 tentang Peradilan Agama.

Wijaya, Gunawan dan Ahmad Yani. Transaksi Bisnis Inernasional: Ekspor-Impor \& Imbal Beli. Jakarta: RajaGrafindo Persada, 2001.

Yuslem, Nawir. Induk Usul Fikib (Konsep Mashlahah Imam al-Haramain al-Juwayni dan Dinamika Hukum Islam). Bandung: Citapustaka Media, 2007. 